INTERDISCIPLINARIA ARCHAEOLOGICA NATURAL SCIENCES IN ARCHAEOLOGY

\title{
Greco-Italic Amphorae from the Punta Romana Shipwreck (Sardinia - Italy)
}

\author{
Loredana Carratoni ${ }^{\mathrm{a}}$, Martina Iezzi ${ }^{\mathrm{b}}$, Constantino Meucci ${ }^{\mathrm{b}}$ \\ ${ }^{a}$ Department of Earth Sciences, Sapienza University of Rome, Piazzale Aldo Moro, 5, 00185 Rome, Italy \\ ${ }^{b}$ Studio C. Meucci, Via di San Tarcisio 62, 00178 Roma, Italy
}

\section{ARTICLE INFO}

\section{Article history:}

Received: $20^{\text {th }}$ June 2016

Accepted: $28^{\text {th }}$ December 2016

\section{Key words:}

amphorae

Greco-Italic

shipwreck

petrography

chemical composition

provenance

Campania

Ischia

\begin{abstract}
A B S TRACT
The remains of the amphorae cargo wrecked close to Punta Romana (Capo Ferrato - Sardinia) has been analyzed through archaeological comparison with well-known typologies, and also by mineralogic, petrographic and chemical analyses in order to ascertain the provenance of the ceramics. The fragments have been identified as Greco-Italic amphorae types MGS III and MGS III-IV produced in the Ischia and Campania kilns in the $4^{\text {th }}-3^{\text {rd }}$ century BC. SEM-EDS analyses confirmed the origin from the Campania region, while petrography and XRD analyses allowed two different production areas of the shipwreck cargo to be ascertained, namely: the Lacco Ameno furnaces on the island of Ischia; and the furnaces operating in the Capua district.
\end{abstract}

\section{Introduction}

The ceramics analyzed come from the shipwreck of Punta Romana that is located on the coast of Capo Ferrato (Muravera - Sardinia) at a depth ranging from about 12 to 25 metres. The archaeological remains are dispersed over a wide area owing to the force of the waves impacting on the basaltic rocks of the promontory and the residual ceramics are deeply fragmented. However, contrary to their theft by divers and the destructive activity of the sea, several fragments of diagnostic value may still be found among the seabed rocks (Figure 1), often protected by the Posidonia oceanica seagrass growing about the site. The possible presence of a shipwreck is announced by the presence of two iron anchors lying a few metres away, though yet unstudied, while there is no evidence of any wooden remains of the hull.

Although the site has been known from some time ago, the wreck has never been studied and its existence is only mentioned in the list of shipwrecks pertaining to the

*Corresponding author. E-mail: costantino.meucci@libero.it
Mediterranean by Gianfrotta and Pomey (1981); however, underwater exploration of the coast from Capo Ferrato to Villasimius has confirmed that the wreck noticed by these two authors probably refers to a Roman shipwreck with a cargo of bricks and tiles lying offshore the small Isola dei Cavoli in front of the Villasimius harbor.

The survey carried out in 2011 along the coast of Capo Ferrato (Figure 2) ascertained the wide dispersion of the cargo and gave an opportunity to sample some significant elements that referred to the same pottery typology, which was recognizable as Greco-Italic amphorae.

\subsection{The Greco Italic amphorae}

The term "Greco-Italic" was used for the first time in the 1950 s by Fernand Benoit (1958) to define a group of 400 amphorae discovered in several underwater sites close to Marseilles (Will 1982). The studies regarding this peculiar typology of ceramic containers started with the development of underwater archaeology, since the amphorae are the most abundant artefacts comprising the cargo of shipwrecks. In particular, the Greco-Italic amphorae represent the principal 


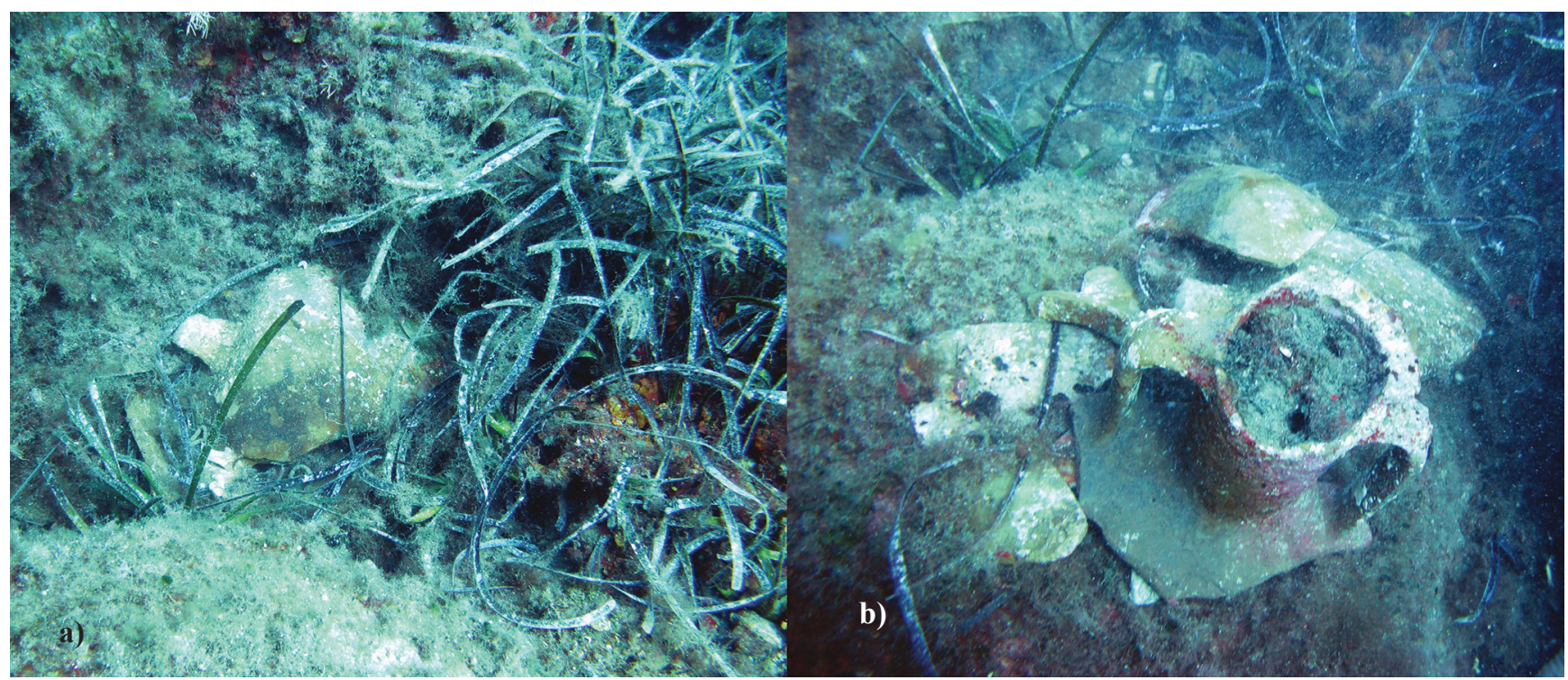

Figure 1. The amphorae fragments in their seabed location: a) Sample PR4; b) Sample PR1.

container used between the $4^{\text {th }}$ and $2^{\text {nd }}$ century $\mathrm{BC}$ for the commerce of wine in the Mediterranean area, as confirmed by a synthetic analysis on the diffusion of the Greco-Italic amphorae in the Mediterranean basin made by Rossi (2000) with particular reference to finds recovered during the excavation of the Ancient Harbour of Pisa.

As reported by Long (1987), Greco-Italic amphorae of the Grand Congloué shipwreck can be dated back to between the end of the $3^{\text {rd }}$ and start of the $2^{\text {nd }}$ century BC. The same dating is proposed by Costantini (2011) for fragments recovered in the excavations of Piazza Duomo in Pisa, although the production of this peculiar typology of amphorae started in the $4^{\text {th }}$ century $\mathrm{BC}$. However, the profile of the rim of the amphorae from the latter two sites differs from that of the fragments collected in the Capo Ferrato site (Figure 3) owing to the different inclination of the lip.

According to several authors, the shape of the Greco Italic amphorae modified over time owing to their different areas of production as well as their dating. The most evident modifications involved both the rim profile and the base, while the body shape is quite invariant (Py at al. 2001).

An overview of the archaeological questions related to these materials was provided by Olcese (2007) and the most important ones are connected to the identification of their origin (Greece or Greek colonies of the south of Italy) and the localization of the production centres of this typology

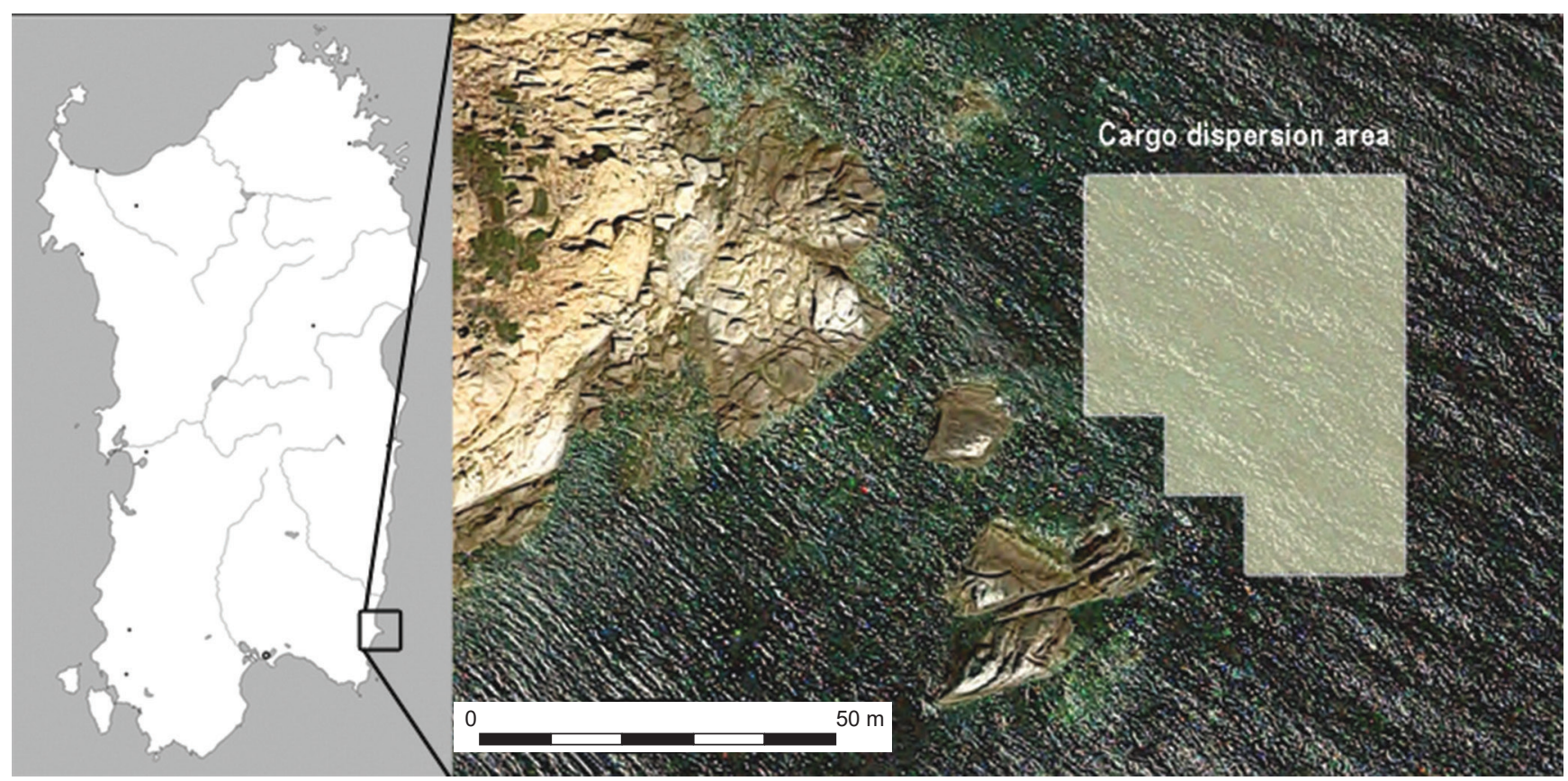

Figure 2. The area investigated with the underwater survey (from Google Maps). 


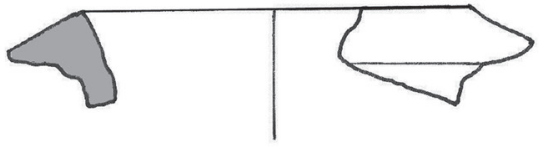

Constantini

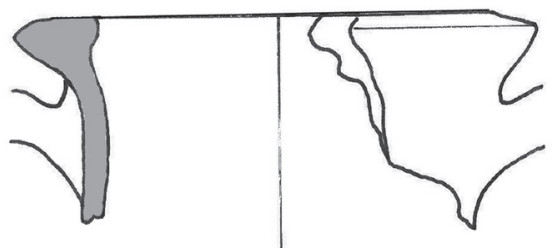

Olcese III \& III-IV

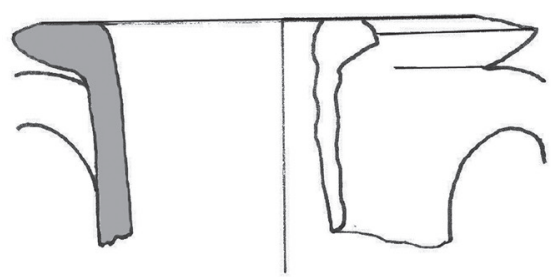

Olcese IV

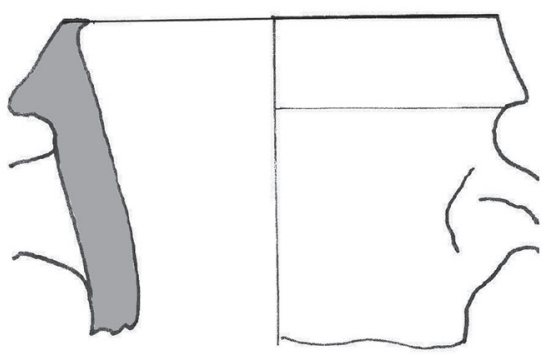

Benoit

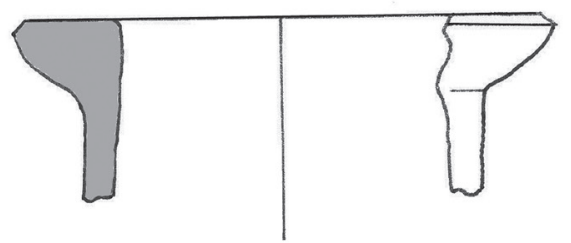

PR 2

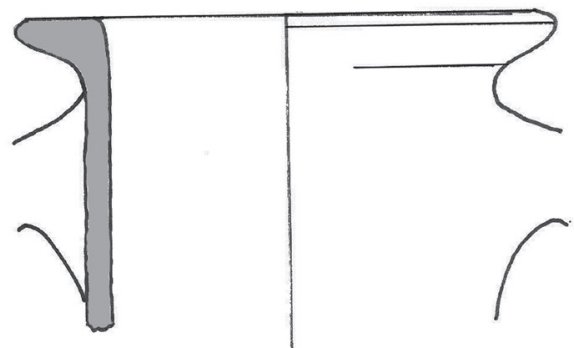

PR 1

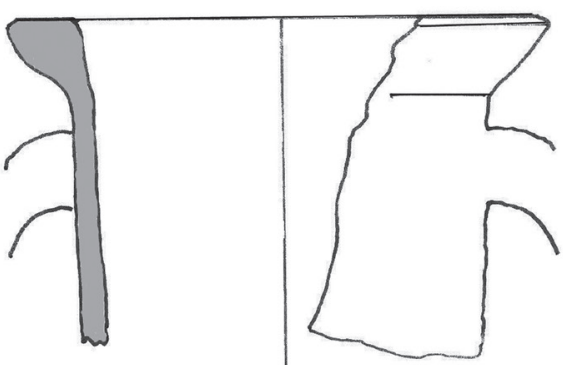

PR 5

Figure 3. Rim types of the Greco-Italic amphorae from several sites and authors. Elaborated by the authors from Costantini 2011, Olcese 2012 and Benoit 1958.

of amphora. At present, many production areas have been localized - varying from the southern regions of the ancient Etruria to the Gulf of Naples in the so-called Tyrrhenian volcanic belt (Cibecchini, Capelli 2013). However, most of the production areas are concentrated in southern Italy, such as in Campania and Sicily, according to Olcese (2012), who recognized several interesting production furnaces on the island of Ischia, among which our samples may probably be located. In particular, looking at the rim shape, the fragments from Punta Romana seem to be very similar to those of the Lacco Ameno types MGS III and MGS III-IV dating back to the $4^{\text {th }}$-early $3^{\text {rd }}$ century BC.

Referring to this chronological and typological framework, one of the goals of the present work is to find the archaeometric data necessary to individuate the most probable provenance of the Greco-Italic amphorae found in the site of Punta Romana.

\section{Materials and methods}

The analyzed ceramics can be ascribed to the Greco-Italic type, with peculiar reference to the MGS III or MGS IIIIV typology ascribed by Olcese (2012) to the production of Ischia that dates back to the $4^{\text {th }}-3^{\text {rd }}$ century BC. In particular, the fragments pertain respectively to a base (PR6), two edges with part of the neck (PR2 and PR5), two shoulders with part of the handles (PR3 and PR4) and the upper part of an amphora with handles and part of the rim (PR1); all samples are shown in Figure 4. The diagnostic fragments recovered for documentation and sampling have been relocated to their original places in order not to modify the archaeological significance of the site.

Petrographic analysis were carried out on six thin sections, which were obtained by embedding small fragments extracted from the samples into synthetic resin, using a polarizing 

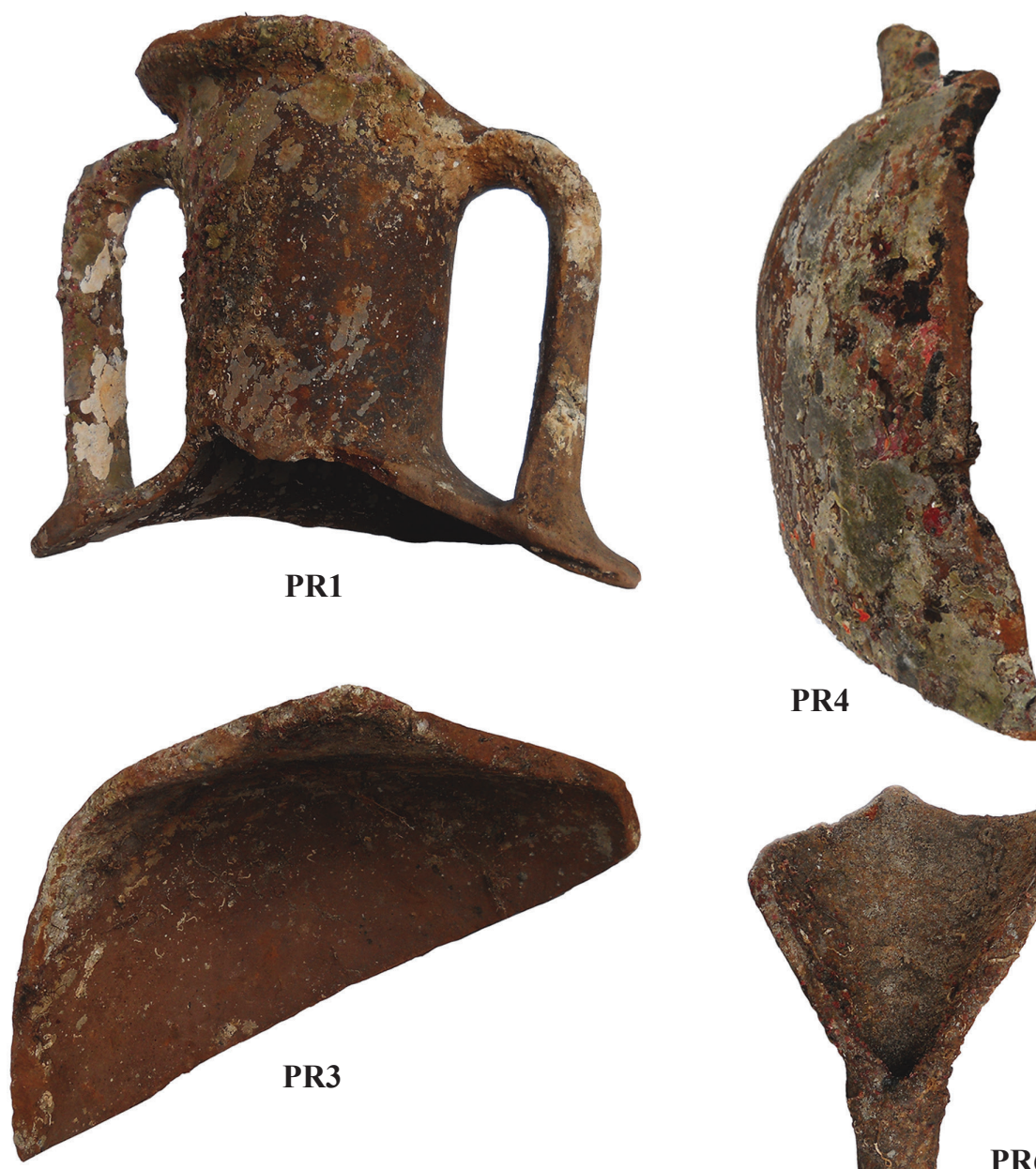

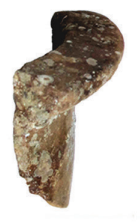

PR2

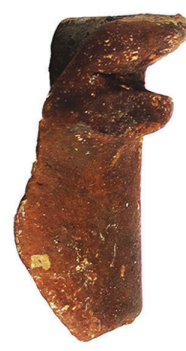

PR5

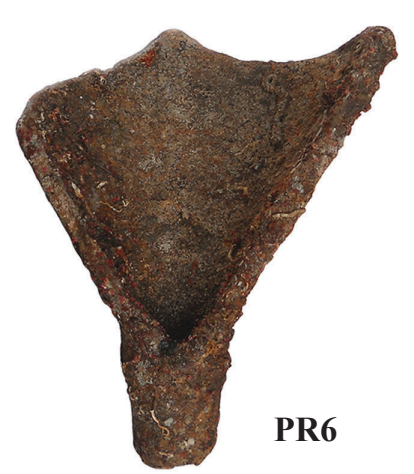

Figure 4. Diagnostic materials from the Punta Romana shipwreck site.

microscope Leitz Ortholux II to obtain information on the characteristics and mineral composition of the ceramic paste.

The mineralogical composition of the powdered samples has been established in random conditions by X-Ray diffractometry by means of a Seifert instrument equipped with an X-Ray tube using Cu k-alpha radiation $(\lambda=1.5405 \AA)$. The specimens were analyzed in the $2 \theta$ range from $4^{\circ}$ to $65^{\circ}$ and a scanning angle rate of $0.02 \% \mathrm{~min}$.

The chemical composition has been obtained by SEM-EDS, using a LEO1450VP microscope equipped with a microanalysis system INCA 300 for quantitative determination, analyzing (three measurements for each sample) the random powdered samples properly compacted on an adhesive support in order to have a flat surface that reduces the influence of the sample geometry and enables all analyses to be performed in the same conditions.

\section{Results}

Comparing the mineralogical composition obtained by XRD analyses confirms that the ceramics are similar in terms of temper contribution. Indeed, quartz predominates in all samples, while calcite remains in the minority along with dolomite (Figure 5). K-Feldspars and plagioclases are mixed in comparable quantities confirming that the temper fraction 


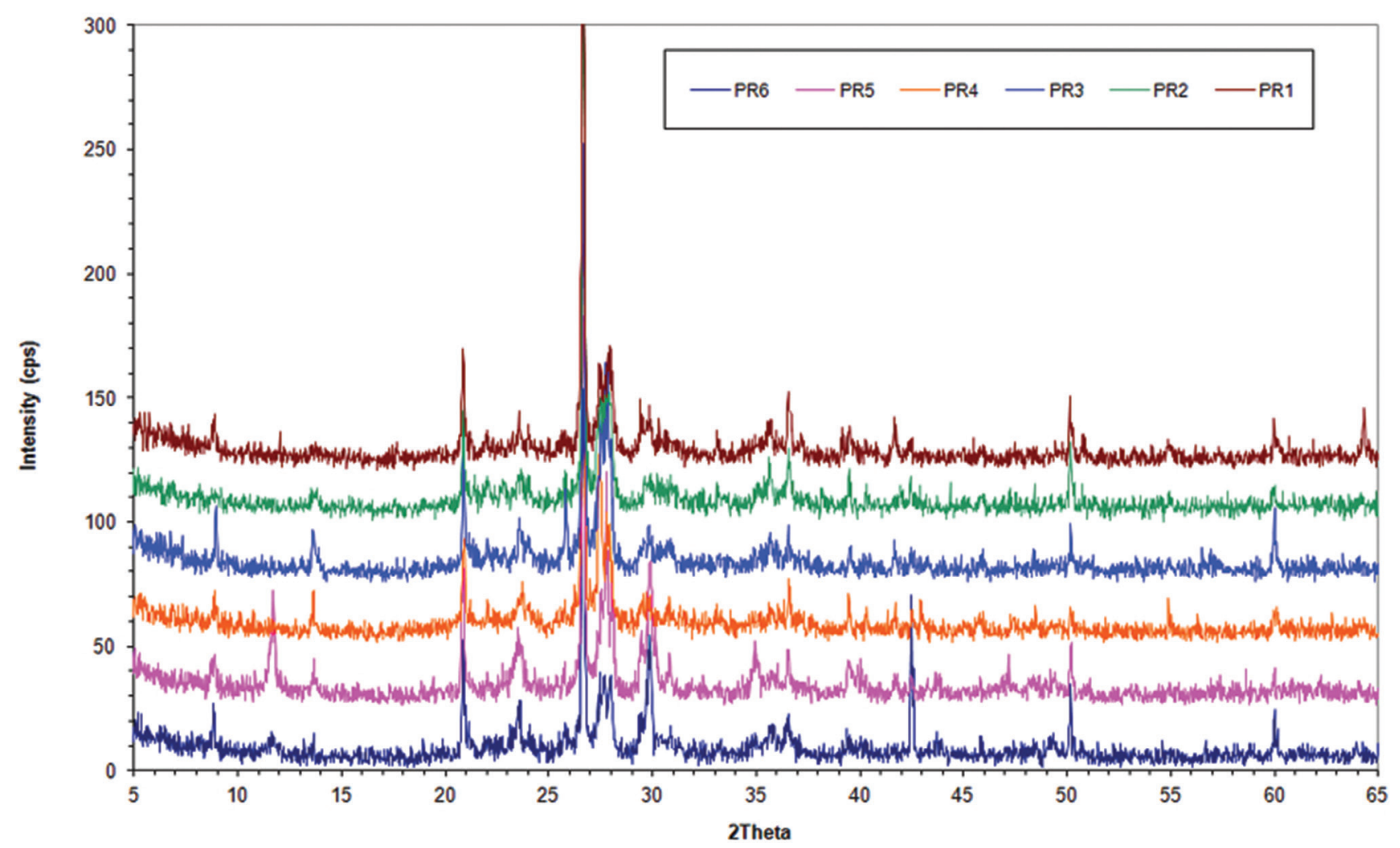

Figure 5. Comparison of the random XRD spectra of the ceramic samples.

was probably obtained by mixing sands from different origins, as confirmed by the presence of pyroxenes that come from volcanic areas.

The composition of each sample has been better ascertained by petrographic analyses performed on thin cross-sections. Figure 6 illustrates the most important characteristics of the samples, summarized in Table 1.
Samples PR5 and PR6 show only an optically-active matrix containing both microcrystalline calcite and quartz, as well as micas. Micro-fossils are also present in these samples, confirming that the clay comes from a depositional basin. As for their temper composition, the rocks commonly present are limestone, generally in semi-rounded particles, and round fragments of olivine-basalt, sometimes mixed

Table 1. Results of the petrographic analyses. Legend: Colours indicate pertinence to the same class of component, as well as their presence in the sample.

\begin{tabular}{|c|c|c|c|c|c|c|c|c|c|c|c|c|c|c|c|c|c|c|c|c|c|c|c|c|c|}
\hline \multirow[b]{3}{*}{ 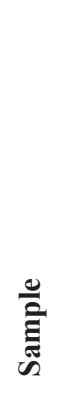 } & \multicolumn{7}{|c|}{ Matrix } & \multicolumn{18}{|c|}{ Temper } \\
\hline & \multirow[b]{2}{*}{ 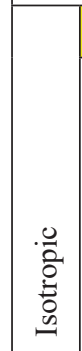 } & \multicolumn{3}{|c|}{ Micritic } & \multicolumn{3}{|c|}{ Fossils } & \multicolumn{7}{|c|}{ Rocks } & \multicolumn{11}{|c|}{ Minerals } \\
\hline & & $\frac{\mathscr{0}}{\frac{0}{\pi}}$ & 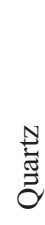 & $\stackrel{\mathscr{J}}{\stackrel{\mathscr{J}}{\Sigma}}$ & 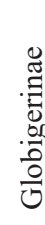 & $\begin{array}{l}\frac{y}{\mathrm{~s}} \\
\bar{\equiv} \\
\stackrel{0}{\Sigma}\end{array}$ & 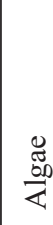 & & & $\begin{array}{l}0 \\
0 \\
0 \\
0 \\
0 \\
0 \\
0\end{array}$ & $\begin{array}{l}\stackrel{g}{0} \\
\frac{0}{0} \\
\frac{0}{2}\end{array}$ & 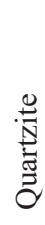 & . & $\begin{array}{l}0 \\
\frac{0}{0} \\
0 \\
.0 \\
\frac{0}{0} \\
\frac{0}{0}\end{array}$ & 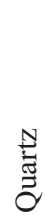 & 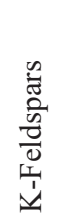 & $\begin{array}{l}0 \\
0 \\
\frac{0}{0} \\
\frac{0}{00} \\
\frac{\pi}{2} \\
\end{array}$ & 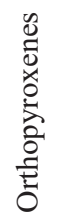 & 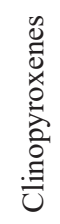 & 音 & 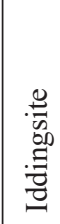 & 营 & 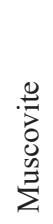 & 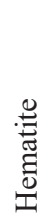 & $\frac{\frac{\pi}{0}}{\frac{\pi}{\pi}}$ \\
\hline PR 1 & YES & & & & & & & & & & & & & & & & & & & & & & & & \\
\hline PR 2 & YES & & & & & & & & & & & & & & & & & & & & & & & & \\
\hline PR 3 & YES & & & & & & & & & & & & & & & & & & & & & & & & \\
\hline PR 4 & YES & & & & & & & & & & & & & & & & & & & & & & & & \\
\hline PR 5 & $\mathrm{NO}$ & & & & & & & & & & & & & & & & & & & & & & & & \\
\hline PR 6 & NO & & & & & & & & & & & & & & & & & & & & & & & & \\
\hline
\end{tabular}




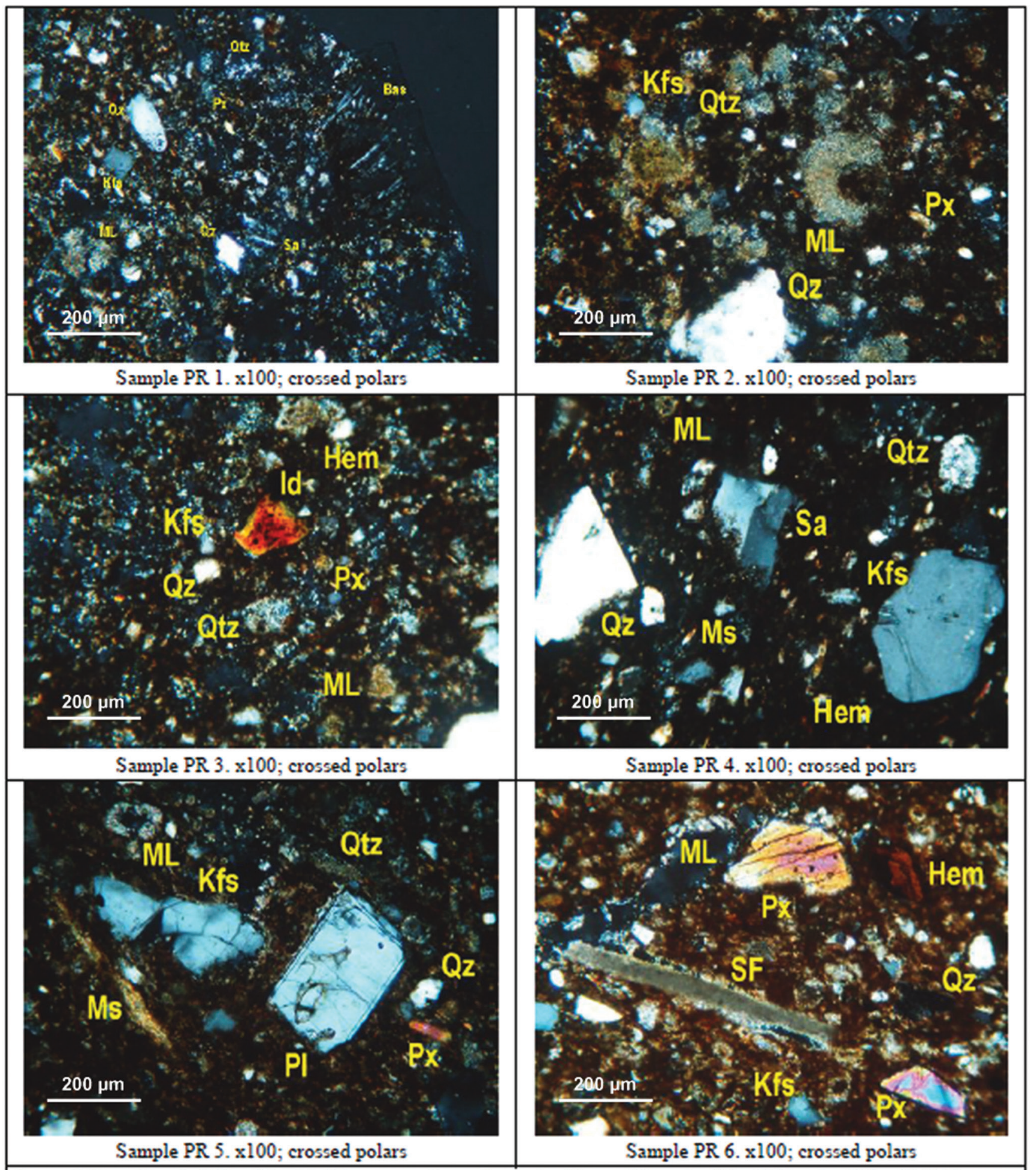

Figure 6. Petrographic analysis separates out the components of the temper, and the optical properties of the matrix. Legend: Bas $=$ Basalt, $\mathrm{ML}=$ Micritic Limestone, Qtz = Quartzite, Hem = Hematite, Id = Iddingsite, Kfs = K-Feldspar, Ms = Muscovite, Pl= Plagioclase, Px = Pyroxene, Qz = Quartz, $\mathrm{Sa}=$ Sanidine, $\mathrm{SF}=$ Shell Fragment

with pumice and volcanic glass; the phonolite and quartzite are generally angularly shaped. Quartz and K-feldspars are abundant in the mineral fraction, with sanidine prevailing among the microcline and orthoclase. Plagioclases are also diffused in the temper and may be attributed to albite and labradorite, which are the main components of basalt. Pyroxenes are present in their different varieties, but diopside is the most abundant, as confirmed by the XRD analyses. Olivine is often altered to iddingsite, and may be used as a marker component. By contrast, micas are ubiquitous and do 
Table 2. Chemical composition of the analyzed samples (wt $\% \pm 0.1 \%$ ).

\begin{tabular}{lccccccccc}
\hline Sample & $\mathbf{S i O}_{2}$ & $\mathbf{A l}_{2} \mathbf{O}_{3}$ & $\mathbf{C a O}$ & $\mathbf{F e}_{2} \mathbf{O}_{3}$ & $\mathbf{M g O}$ & $\mathbf{N a}_{2} \mathbf{O}$ & $\mathbf{K}_{2} \mathbf{O}$ & $\mathbf{T i O}_{2}$ & $\mathbf{S u m}$ \\
\hline PR1 & 53.9 & 17.4 & 9.5 & 6.5 & 6.9 & 2.4 & 2.8 & 0.7 & 100.0 \\
PR2 & 57.4 & 15.0 & 7.5 & 9.8 & 4.3 & 2.3 & 2.7 & 1.1 & 100.0 \\
PR3 & 55.9 & 14.3 & 9.6 & 10.9 & 3.6 & 2.5 & 2.5 & 0.5 & 100.0 \\
PR4 & 54.1 & 16.8 & 10.1 & 7.3 & 4.8 & 2.6 & 3.2 & 0.9 & 100.0 \\
PR5 & 46.5 & 16.4 & 15.9 & 6.7 & 9.4 & 1.6 & 2.7 & 0.7 & 100.0 \\
PR6 & 51.1 & 16.2 & 14.6 & 6.8 & 6.2 & 1.5 & 2.7 & 0.8 & 100.0 \\
\hline
\end{tabular}

not have diagnostic significance, as does hematite, due to the firing temperature and conditions, and calcite, which is of secondary origin.

The chemical composition of the samples from the SEMEDS analyses is summarized in Table 2.

From the table, it clearly appears that all samples have the same composition except for the $\mathrm{CaO}$ content of samples PR5 and PR6, where $\mathrm{MgO}$ is also higher than in the other samples owing to the presence in the temper of traces of dolomite, as confirmed by the XRD analyses.

\section{Discussion}

The analytical results make it possible to divide the samples into two groups. The first cluster contains the samples from PR1 to PR4 and is characterized by their isotropic matrix and the presence in the temper of olivine degraded to iddingsite, which is the result of the transformation of olivine under hydrothermal conditions. This mineral is relatively common in the volcanic outcrops of Ischia (Fedele, Morra 2011), where the strong hydrothermal activity activates this process.

The second cluster only contains the samples PR5 and PR6 and is characterized by an optically-active matrix due to the contemporary presence of micritic calcite and fossils that may be referred to Foraminifera and sporadically to Mollusks and Algae. This implies the use of a clay formed in an alluvial environment like that of the Volturno river basin in the Capua district (De Bonis at al. 2013), where, in ancient times, many outcrops of clay were cultivated for the extraction of the raw material for the production of ceramics, as confirmed by De Bonis (2010). Thus, the analytical data allows the hypothesis of a dual provenance for the Punta Romana amphorae, both located in the Gulf of Naples area:

Figure 7. Distribution of the Punta Romana samples and of the reference samples from Sicily and Campania (Barone at al. 2011) and Ischia (Olcese 2012) according to their chemical composition.

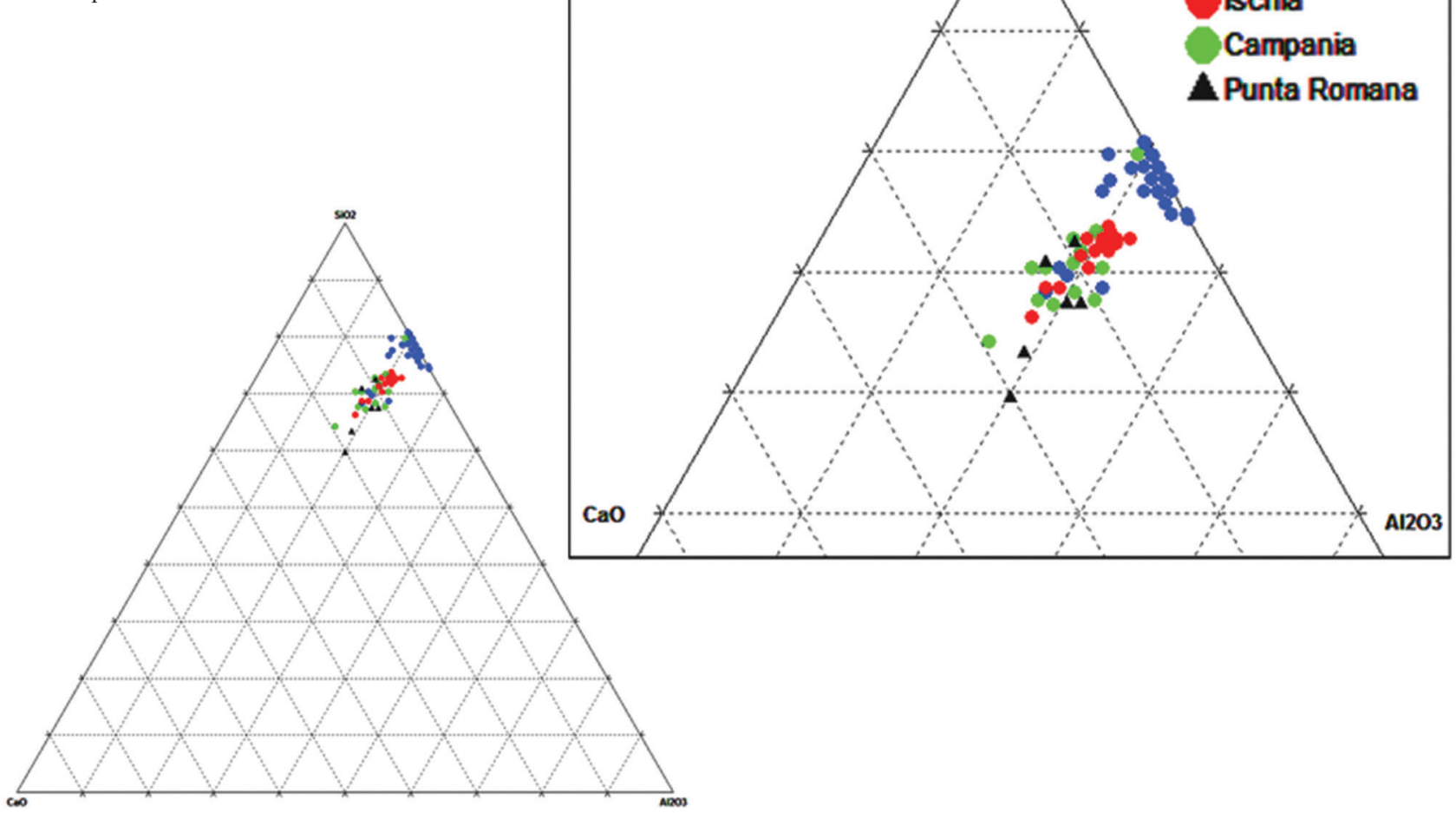


the first cluster comes from Ischia, while the second comes from the Capua region, according to the information reported in De Bonis at al. (2014).

Comparison of the chemical composition of the Punta Romana samples with those extracted from the literature of authors that extensively studied the Greco-Italic amphorae production confirms this hypothesis.

Indeed, the ceramics produced in Sicily are located in a very restricted cluster (Figure 7) characterized by the highest content of $\mathrm{SiO}_{2}$ (Barone at al. 2011). By contrast, the Campania productions describe a larger cluster that also contains the amphorae produced in the furnaces of Ischia (Olcese 2012); indeed, the latter refer to the III and IIIIV rim types that are similar to that of the Punta Romana shipwreck and were produced in the Santa Restituta kilns in the Lacco Ameno district. As in the figure, the first cluster of Punta Romana amphorae is included in the Ischia production, while the second cluster is located at the boundaries of the large Campania cluster owing to its high content of $\mathrm{CaO}$.

The distribution of $\mathrm{CaO} \mathrm{wt} \%$ content against $\mathrm{SiO}_{2}$ (Figure 8a) verifies that the quality and origin of the clays differ according to their origin. The Greco-Italic amphorae produced in Sicily contain very low calcite, while the calcium content increases in the productions from the Campania region, including the Ischia types that are intermediate. However, the content values of $\mathrm{CaO}$ and $\mathrm{SiO}_{2}$ vary with good correlation, confirming that the composition of the raw material deeply affects the chemical composition of the fabric. Figure $8 \mathrm{~b}$ highlights how the composition of the temper fraction affects the distribution of the ceramics; indeed, the high content of the aluminum oxide in the Campania productions suggests that, in this case, the temper content is greater than in the Sicilian production, but also that the mineral composition differs as well. This is confirmed by Figures $8 \mathrm{c}$ and $8 \mathrm{~d}$, where the content of $\mathrm{CaO}$ and $\mathrm{K}_{2} \mathrm{O}$, respectively, are shown against the $\mathrm{Na}_{2} \mathrm{O}$ content. In both cases, the Sicilian productions differ from that of the Campania region in their abundance of calcite (Figure 8c), and because the Campania productions are richest in plagioclases owing to the different acidity of their volcanic district of origin. In all cases, the samples from the Punta Romana shipwreck locate to the Campania production cluster and are very close to the samples fired in the kilns of Ischia.

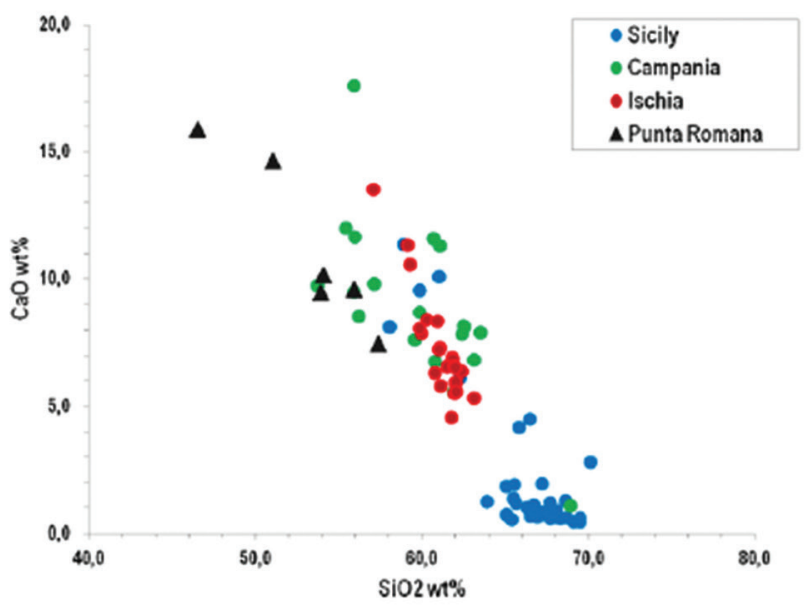

a)

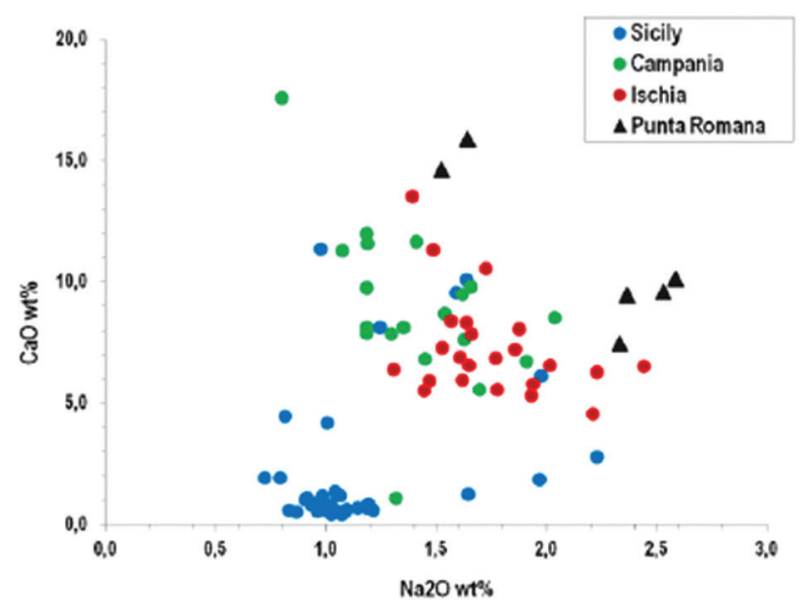

c)

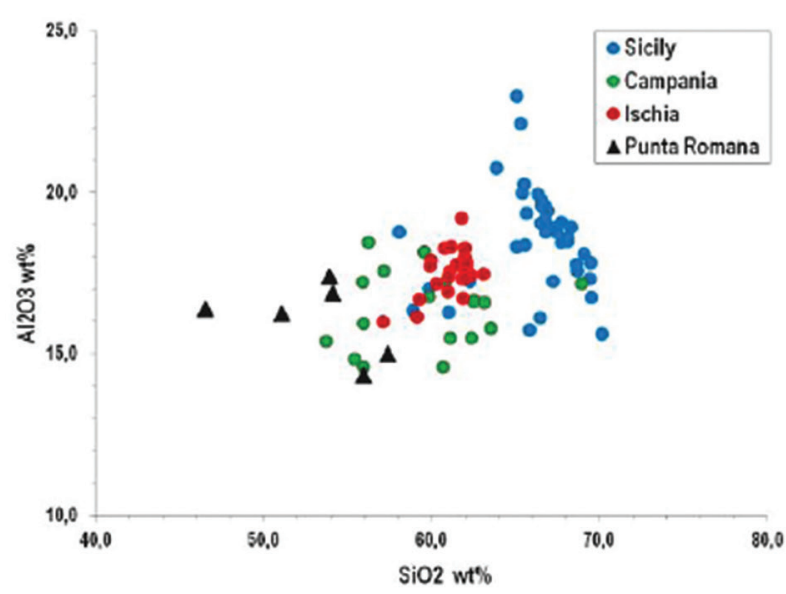

b)

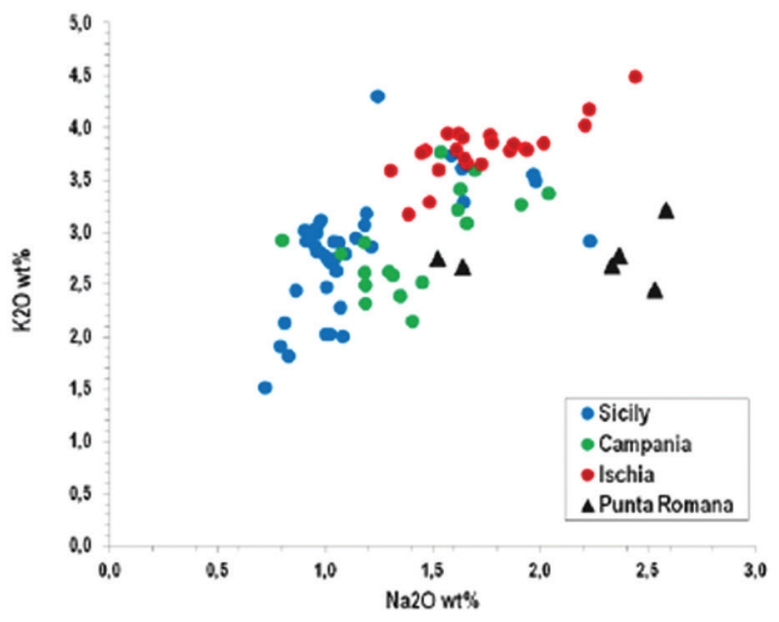

d)

Figure 8. Different correlation graphs among some chemical components of the Greco-Italic amphorae. 


\section{Conclusion}

The comparison of the Punta Romana fragments with Greco-Italic amphorae produced in the Lacco Ameno (Ischia) furnaces induces the hypothesis that the shipwreck cargo pertains to the III and III-IV types dating back to the $4^{\text {th }}$ century BC. (Olcese 2012).

The chemical composition data confirm that all samples from Punta Romana were produced in the Campania region, but also that they pertain to two different production centres. Samples PR1, PR2, PR3 and PR4 were produced in the furnaces of Ischia, as confirmed by the presence in the temper fraction of olivine transformed to iddingsite, according to the hydrothermal conditions of the island. By contrast, although the rim shape is the same, samples PR5 and PR6 were produced in the Capua district where marl-clay containing Foraminifera outcrops extensively. Thus, the Punta Romana cargo seems to be mainly composed by amphorae coming from the Campania region, which is also where they have been produced. As for the commercial route, in the absence of exhaustive archaeological studies of the site, we may only hypothesize that the ship was sailing along the oriental coast of Sardinia following a route well protected from the NW wind. This route seems to be preferred by ships heading towards the harbour of Olbia, which had been the centre of the maritime traffic starting from the $6^{\text {th }}$ century BC (D'Oriano 2004), but also by those headed towards the Massilia harbour that was preferably reached sailing along the Tirrenian coast (Cibecchini 2011). As for the $1^{\text {st }}$ century AD shipwreck found in 1992 only three miles to the south of Punta Romana (Salvi 1994), it is impossible to ascertain the final destination of the Punta Romana ship; however, the Campania origin of the cargo allows to hypothesize that this region was probably the starting point of their journey. Owing to the ascertained use of the Greco-italic amphorae for transporting wine, the finds of Punta Romana may contribute towards the confirmation of the importance of the routes of eastern Sardinia for the wine trade in the Mediterranean world.

\section{Acknowledgements}

The authors wish to thank the Soprintendenza Archeologica di Cagliari for the permission to study the shipwreck site of Punta Romana and publish the results. Special thanks must go to Dr. Daniela Ferro of the CNR Rome for helping us in the SEM-EDS analyses; we wish also to thank Prof. Adriana Maras who was one of the supervisors of the thesis made by Dr. M. Iezzi in 2010.

\section{References}

BARONE, G., MAZZOLENI, P., INGOGLIA, C., VANARIA, M. G. 2011: Archaeometric evidences of the $4^{\text {th }}-2^{\text {nd }}$ century BC amphorae productions in north eastern Sicily. Journal of Archaeological Science 38, 3060-3071. BENOIT, F. 1958: Nouvelles épaves de Provence. Gallia 16/1, 5-39.

CIBECCHINI, F. 2011: Rotte e commerci marittimi in età romana: possibilità interpretative e relazioni con il territorio dei principali relitti noti in Etruria. In: Petralia, G. (Ed.): I sistemi portuali della Toscana mediterranea. Infrastrutture, scambi, economie dall'antichità a oggi, Pacini Editore. Pisa, 11-19.

CIBECCHINI, F., CAPELLI, C. 2013: Nuovi dati archeologici e archeometrici sulle anfore greco-italiche: i relitti di III secolo del Mediterraneo occidentale e la possibilità di una nuova classificazione. In: Olmer, F. (Ed.): Itinéraires des vins romains en Gaule IIIe-Ier siècles avant J.-C. Confrontation de faciès, Actes du colloque européen organisé par l'UMR 5140 du CNRS. Lattes, 30 janvier-2 février 2007, Monographies d'Archéologie Méditerranéenne, Hors-série n5, 423-451.

COSTANTINI, A. 2011: Le anfore. In: Alberti, A., Paribeni, E. (Eds.): Archeologia in Piazza dei Miracoli. Gli scavi 2003-2009, Felici Editore, Pisa, 293-430.

DE BONIS, A. 2010: Caratterizzazione mineralogico-petrografica e fisico-meccanica di argille campane quali materie prime per produzioni ceramiche d'interesse archeologico. PhD Thesis in Petrography and Petrology, XXIII cycle. Deposited: University of Catania \& University of Naples "Federico II".

DE BONIS, A., GRIFA, C., CULTRONE, G., DE VITA, P., LANGELLA, A., MORRA, V. 2013: Raw Materials for Archaeological Pottery from the Campania Region of Italy: A Petrophysical Characterization. Geoarchaeology 28, 478-503.

DE BONIS, A., CULTRONE, G., GRIFA, C., LANGELLA, A., MORRA, V. 2014: Clays from the Bay of Naples (Italy): New insight on ancient and traditional ceramics. Journal of the European Ceramic Society 34/13, 3229-3244.

D'ORIANO, R. 2004: Relitti di storia: lo scavo del Porto di Olbia. In: Giacobelli, M. (Ed.): Lezioni Fabio Faccenna II. Casa Editrice Edipuglia, 63-74.

FEDELE, L., MORRA, V. 2011: Il distretto vulcanico dei Campi Flegrei. Geoitalia 35, 18-27.

GIANFROTTA, P. A., POMEY, P. 1981: Archeologia subacquea: storia, tecniche, scoperte e relitti. Mondadori, Milan.

LONG, L. 1987: Les épaves du Grand Congloué. Etude du journal de fouille de Fernand Benoit. Archaeonautica 7, 9-36.

OLCESE, G. 2007: The production and circulation of Greco-Italic amphorae of Campania (Ischia/Bay of Naples). The data of the archaeological and archaeometric research. SKYLLIS, 60-75.

OLCESE, G. 2012: Le anfore greco italiche di Ischia: archeologia e archeometria. Artigianato ed economia nel Golfo di Napoli, Edizioni Quasar, Rome.

PY, M., ADROHER AUROUX, A. M., SANCHEZ, C. 2001: Corpus des céramiques de 1'Âge du Fer de Lattes (fouilles 1963-1999): Tome 1. Lattara 14, 45-72.

ROSSI, E. 2000: Greco-Italic amphorae. In: S. Bruni (Ed.): The ancient ships of Pisa. Polistampa Ed, Florence, 121-129.

SALVI, D. 1994: Antefisse fittili da un relitto nelle acque di Cala Sinzias, Castiadas. Quaderni della Soprintendenza Archeologica di Cagliari e Oristano 11, 263-271.

WILL, E. L. 1982: Greco-italic amphoras. Hesperia: The Journal of the American School of Classical Studies at Athens 51/3, 338-356. 
